\title{
Use of statins in lower extremity artery disease: a review
}

\author{
Giuseppe Gargiulo', Giuseppe Giugliano', Linda Brevetti', Anna Sannino ${ }^{1}$, Gabriele Giacomo Schiattarella', \\ Federica Serino ${ }^{1}$, Andreina Carbone ${ }^{1}$, Fernando Scudiero ${ }^{1}$, Marco Ferrone ${ }^{1}$, Roberto Corrado ${ }^{1}$, Raffaele Izzo ${ }^{1}$, \\ Lorenzo Chiariotti ${ }^{2}$, Cinzia Perrino ${ }^{1}$, Bruno Amato $^{3}$, Bruno Trimarco ${ }^{1}$, Giovanni Esposito ${ }^{1 *}$
}

From XXV National Congress of the Italian Society of Geriatric Surgery

Padova, Italy. 10-11 May 2012

\begin{abstract}
Background: Lower extremity artery disease (LE-PAD) is one of the most common manifestations of atherosclerosis, particularly in elderly patients, and it is related to a high cardiovascular risk.

Description: It is well established that statin therapy is characterized by crucial benefits on cardiovascular system by limiting atherosclerotic progression and reducing cardiovascular events and mortality. A growing body of evidence support efficacy of statins in LE-PAD due to the ability of both reducing cardiovascular risk and improving walking distance and, hence, quality of life. Consequently, statin therapy should be considered in all LE-PAD patients and new LDL-cholesterol targets should be reached.

Conclusions: Our opinion is that statin therapy remains still underutilized or with inadequate dosage, so therapy of LE-PAD patients should be improved to obtain all the demonstrated benefits of statins.
\end{abstract}

\section{Background}

Lower extremity artery disease (LE-PAD) is one of the most common manifestations of atherosclerosis and its frequency is strongly related to age: uncommon before 50 years, rising steeply at older ages. A substantial percentage of patients with chronic coronary artery disease (CAD) have associated cerebrovascular disease, LE-PAD, or both. Consequently, LE-PAD represents a marker of diffuse atherosclerosis implying a high cardiovascular risk [1-3] and, in symptomatic patients, it is also an important cause of disability. Secondary prevention of cardiovascular risk factors is mandatory in all LE-PAD patients to improve cardiovascular prognosis, while revascularization should be restricted to symptomatic patients. In order to improve symptoms and walking distance capacity conservative or invasive approaches (endovascular or surgical revascularization) can be undertaken. The conservative strategy is effective and based on pharmacologic agents

\footnotetext{
* Correspondence: espogiov@unina.it

1 Department of Clinical Medicine and Cardiovascular and Immunology

Sciences, Federico II University, via Pansini 5, 80131, Naples, Italy

Full list of author information is available at the end of the article
}

(anti-platelet, lipid-lowering, antihypertensive; cilostazol; naftidrofuryl; pentoxifylline; carnitine; buflomedil) and exercise therapy, whose beneficial effects on LE-PAD and the cardiovascular system are well established $[1,4]$. While revascularization is recommended in patients with critical limb ischemia (CLI), the evidence of any long-term benefit of endovascular treatment over supervised exercise and best medical treatment is inconclusive, particularly in patients with mild to moderate claudication. However, advances in the endovascular treatment of LE-PAD have prompted many physicians to consider more liberal indications for percutaneous intervention. Endovascular revascularization is also indicated in patients with lifestylelimiting claudication when clinical features suggest a reasonable likelihood of symptomatic improvement and there has been an inadequate response to conservative therapy. In aorto-iliac lesions, endovascular revascularization can be considered without initial extensive conservative treatment. Endovascular revascularization for the treatment of patients with LE-PAD has developed rapidly during the past decade, and a great number of patients can now be offered the less invasive treatment option.
C Biomed Central

() 2012 Gargiulo et al; licensee BioMed Central Ltd. This is an Open Access article distributed under the terms of the Creative Commons Attribution License (http://creativecommons.org/licenses/by/2.0), which permits unrestricted use, distribution, and reproduction in any medium, provided the original work is properly cited. 
Despite numerous advantages, the major drawback of endovascular interventions, compared with surgery, is the lower long-term patency, mainly due to restenosis [5-9]. However, an increasing number of centres favour an endovascular approach first, due to reduced morbidity and mortality, compared with vascular surgery, while preserving the surgical option in case of failure.

\section{Methods}

Pleiotropic effects and cardiovascular benefits of statin therapy are well-established [10-14], in particular their beneficial effects on atherosclerosis (reduction of cholesterol levels, inhibition of inflammation and plaque stabilization). In addition, statins reduce the risk of mortality, cardiovascular events, and stroke in patients with LE-PAD with and without coronary artery disease (CAD) $[10,11]$.

According to these considerations, LE-PAD treatment has two main objectives: 1) to reduce cardiovascular risk, 2) to improve walking distance and, hence, quality of life. A large body of evidence demonstrates that statins exert positive effects on both. In a retrospective trial, Aronow and Ahn [15] observed a significant reduction of coronary events in 318 LE-PAD patients treated with statins related to 342 untreated patients. Shillinger et al. [16], in a prospective non-randomized trial, described that LE-PAD patients treated with statins had a halved risk of death and myocardial infarction. This latter result was considered predominantly due to the anti-inflammatory effects of statins, since patients with low levels of C-Reactive Protein (CRP) did not evidence a significant benefit from this therapy. Feringa et al. [17], in a 8-years perspective trial, demonstrated that the use of statins was associated to a reduced incidence of death $(\mathrm{HR}=0,46,95 \% \mathrm{CI} 0,58-0,80$, $\mathrm{p}<0.001)$. In the REGRESS trial [18], designed in order to test the effects of two-year-treatment with pravastatin on coronary arteries, it was demonstrated also a significant reduction of carotid and femoral intima-media thickness (assessed by echo-color-doppler) and a significant reduction of cardiovascular events compared to placebo. In the Heart Protection Study [10], a double blind randomized study, 6748 participants had PAD; at 5-year-follow-up, simvastatin-treated patients showed a significant $19 \%$ relative reduction and a $6.3 \%$ absolute reduction in major cardiovascular events related to placebo-treated patients, independently of age, gender, or serum lipid levels.

Beyond the evidence that statins improve the cardiovascular prognosis of patients with LE-PAD, several studies reported preliminary positive effects of statins on intermittent claudication $[19,20]$. The increase in maximal walking distance reported varied, on average, from 50 to $100 \mathrm{~m}$. In one meta-analysis, the pooled effect estimate showed a relevant increase in maximal walking distance of $163 \mathrm{~m}^{16}$. In the $4 \mathrm{~S}$ trial [21], simvastatin reduced incidence or worsening of claudication in hypercholesterolemic patients. McDermott et al. [22] described a better walking performance in LE-PAD patients treated with statins, although these benefits were attenuated when considered CRP levels. The beneficial effects of simvastatin on walking distance in LE-PAD patients were also shown by Aronow et al. and Mondillo et al. [23]. Mohler et al. [24] demonstrated that atorvastatin prolongs walking distance without claudication and improves quality of life. Based on this growing evidence, recent European and American guidelines consider LE-PAD at the same level of CAD, recommending the use of statins in all LE-PAD patients in the absence of contraindication. Particularly, serum LDL cholesterol should be reduced to $<2.5 \mathrm{mmol} / \mathrm{L}$ $(<100 \mathrm{mg} / \mathrm{dL})$, and optimally to $<1.8 \mathrm{mmol} / \mathrm{L}(<70 \mathrm{mg} / \mathrm{dL})$, or $\geq 50 \%$ LDL cholesterol reduction when the target level cannot be reached [1].

\section{Conclusions}

Our opinion is that statin therapy remains still underutilized or with inadequate dosage, so therapy of LE-PAD patients should be improved to obtain all the demonstrated benefits of statins.

\section{Competing interest}

The authors declare that they have no competing interests.

\section{List of abbreviations}

CAD: Coronary artery disease; CLI: Critical limb ischemia; CRP: C-Reactive Protein; LDL: Low density lipoprotein; LE-PAD: Lower extremity artery disease.

\section{Acknowledgements}

This article has been published as part of BMC Surgery Volume 12 Supplement 1, 2012: Selected articles from the XXV National Congress of the Italian Society of Geriatric Surgery. The full contents of the supplement are available online at http://www.biomedcentral.com/bmcsurg/supplements/12/S1.

\section{Author details}

'Department of Clinical Medicine and Cardiovascular and Immunology Sciences, Federico II University, via Pansini 5, 80131, Naples, Italy. ${ }^{2}$ Department of Biology and Cellular and Molecular Pathology, Federico II University, via Pansini 5, 80131, Naples, Italy. ${ }^{3}$ Department of General, Geriatric, Oncologic Surgery and Advanced Technologies, Federico ॥ University, via Pansini 5, 80131, Naples, Italy.

\section{Authors' contribution}

GG, GG: conception and design, drafting the manuscript, given final approval of the version to be published; $L B, A S, G G S, F S, A C, F S, M F, R C, R I$, LC: acquisition of data, drafting the manuscript; CP, BA, BT: critical revision, given final approval of the version to be published;

GE: conception and design, critical revision, given final approval of the version to be published.

Published: 15 November 2012

\section{References}

1. Tendera M, Aboyans V, Bartelink ML, Baumgartner I, Clement D, Collet JP, Cremonesi A, De Carlo M, Erbel R, Fowkes FG, et al: ESC Guidelines on the diagnosis and treatment of peripheral artery diseases: Document covering atherosclerotic disease of extracranial carotid and vertebral, 
mesenteric, renal, upper and lower extremity arteries: the Task Force on the Diagnosis and Treatment of Peripheral Artery Diseases of the European Society of Cardiology (ESC). Eur Heart J 2011, 32(22):2851-2906.

2. Giugliano G, Di Serafino L, Perrino C, Schiano V, Laurenzano E, Cassese S, De Laurentis M, Schiattarella GG, Brevetti L, Sannino A, et al: Effects of successful percutaneous lower extremity revascularization on cardiovascular outcome in patients with peripheral arterial disease. Int J Cardiol 2012.

3. Schiano V, Sirico G, Giugliano G, Laurenzano E, Brevetti L, Perrino C, Brevetti G, Esposito G: Femoral plaque echogenicity and cardiovascular risk in claudicants. JACC Cardiovasc Imaging 2012, 5(4):348-357.

4. Perrino C, Gargiulo G, Pironti G, Franzone A, Scudiero L, De Laurentis M, Magliulo F, llardi F, Carotenuto G, Schiattarella GG, et al: Cardiovascular effects of treadmill exercise in physiological and pathological preclinical settings. Am J Physiol Heart Circ Physiol 2011, 300(6):H1983-1989.

5. Indolfi C, Avvedimento EV, Rapacciuolo A, Di Lorenzo E, Esposito G, Stabile E, Feliciello A, Mele E, Giuliano P, Condorelli G, et al: Inhibition of cellular ras prevents smooth muscle cell proliferation after vascular injury in vivo. Nat Med 1995, 1(6):541-545.

6. Indolfi C, Avvedimento EV, Di Lorenzo E, Esposito G, Rapacciuolo A, Giuliano P, Grieco D, Cavuto L, Stingone AM, Ciullo I, et al: Activation of CAMP-PKA signaling in vivo inhibits smooth muscle cell proliferation induced by vascular injury. Nat Med 1997, 3(7):775-779.

7. Indolfi C, Stabile E, Perrino C, Chiariello M: Mechanisms of restenosis after angioplasty and approach to therapy (Review). Int I Mol Med 1998, 2(2):143-148.

8. Iaconetti C, Polimeni A, Sorrentino S, Sabatino J, Pironti G, Esposito G, Curcio A, Indolfi C: Inhibition of miR-92a increases endothelial proliferation and migration in vitro as well as reduces neointimal proliferation in vivo after vascular injury. Basic Res Cardiol 2012, 107(5):296.

9. Indolfi C, Torella D, Cavuto L, Davalli AM, Coppola C, Esposito G, Carriero MV, Rapacciuolo A, Di Lorenzo E, Stabile E, et al: Effects of balloon injury on neointimal hyperplasia in streptozotocin-induced diabetes and in hyperinsulinemic nondiabetic pancreatic islet-transplanted rats. Circulation 2001, 103(24):2980-2986.

10. MRC/BHF Heart Protection Study of cholesterol lowering with simvastatin in 20,536 high-risk individuals: a randomised placebocontrolled trial. Lancet 2002, 360(9326):7-22.

11. Knopp RH, d'Emden M, Smilde JG, Pocock SJ: Efficacy and safety of atorvastatin in the prevention of cardiovascular end points in subjects with type 2 diabetes: the Atorvastatin Study for Prevention of Coronary Heart Disease Endpoints in non-insulin-dependent diabetes mellitus (ASPEN). Diabetes Care 2006, 29(7):1478-1485.

12. Indolfi C, Cioppa A, Stabile E, Di Lorenzo E, Esposito G, Pisani A, Leccia A, Cavuto L, Stingone AM, Chieffo A, et al: Effects of hydroxymethylglutaryl coenzyme $A$ reductase inhibitor simvastatin on smooth muscle cell proliferation in vitro and neointimal formation in vivo after vascular injury. J Am Coll Cardiol 2000, 35(1):214-221.

13. Indolfi C, Di Lorenzo E, Perrino C, Stingone AM, Curcio A, Torella D, Cittadini A, Cardone L, Coppola C, Cavuto L, et al: Hydroxymethylglutaryl coenzyme A reductase inhibitor simvastatin prevents cardiac hypertrophy induced by pressure overload and inhibits p21ras activation. Circulation 2002, 106(16):2118-2124.

14. Perrino C, Schiattarella GG, Magliulo F, llardi F, Carotenuto G, Gargiulo G, Serino F, Ferrone M, Scudiero F, Carbone A, et al: Cardiac Side Effects of Chemotherapy: State of Art and Strategies for a Correct Management. Curr Vasc Pharmacol 2012.

15. Aronow WS, Ahn C: Frequency of new coronary events in older persons with peripheral arterial disease and serum low-density lipoprotein cholesterol $>$ or $=125 \mathrm{mg} / \mathrm{dl}$ treated with statins versus no lipidlowering drug. Am J Cardiol 2002, 90(7):789-791.

16. Schillinger $M$, Exner $M$, Mlekusch W, Amighi J, Sabeti $S$, Muellner $M$, Rumpold $\mathrm{H}$, Wagner $\mathrm{O}$, Minar E: Statin therapy improves cardiovascular outcome of patients with peripheral artery disease. Eur Heart J 2004, 25(9):742-748.

17. Feringa $H H$, van Waning VH, Bax JJ, Elhendy A, Boersma E, Schouten $\mathrm{O}$, Galal W, Vidakovic RV, Tangelder MJ, Poldermans D: Cardioprotective medication is associated with improved survival in patients with peripheral arterial disease. J Am Coll Cardiol 2006, 47(6):1182-1187.
18. de Groot E, Jukema JW, van Boven AJ, Reiber JH, Zwinderman AH, Lie KI, Ackerstaff RA, Bruschke AV: Effect of pravastatin on progression and regression of coronary atherosclerosis and vessel wall changes in carotid and femoral arteries: a report from the Regression Growth Evaluation Statin Study. Am J Cardiol 1995, 76(9):40C-46C.

19. Momsen AH, Jensen MB, Norager CB, Madsen MR, Vestersgaard-Andersen $T$, Lindholt JS: Drug therapy for improving walking distance in intermittent claudication: a systematic review and meta-analysis of robust randomised controlled studies. Eur J Vasc Endovasc Surg 2009, 38(4):463-474.

20. Erez G, Leitersdorf E: The rationale for using HMG-CoA reductase inhibitors ('statins') in peripheral arterial disease. Eur J Vasc Endovasc Surg 2007, 33(2):192-201.

21. Pedersen TR, Kjekshus J, Pyorala K, Olsson AG, Cook TJ, Musliner TA, Tobert JA, Haghfelt T: Effect of simvastatin on ischemic signs and symptoms in the Scandinavian simvastatin survival study (4S). Am J Cardiol 1998, 81(3):333-335.

22. Vidula H, Tian L, Liu K, Criqui MH, Ferrucci L, Guralnik JM, Green D, Ridker P, McDermott MM: Comparison of effects of statin use on mortality in patients with peripheral arterial disease with versus without elevated C-reactive protein and d-dimer levels. Am J Cardiol 2010, 105(9):1348-1352.

23. Mondillo S, Ballo P, Barbati R, Guerrini F, Ammaturo T, Agricola E, Pastore M, Borrello $F$, Belcastro M, Picchi A, et al: Effects of simvastatin on walking performance and symptoms of intermittent claudication in hypercholesterolemic patients with peripheral vascular disease. Am J Med 2003, 114(5):359-364.

24. Mohler ER 3rd, Hiatt WR, Creager MA: Cholesterol reduction with atorvastatin improves walking distance in patients with peripheral arterial disease. Circulation 2003, 108(12):1481-1486.

doi:10.1186/1471-2482-12-S1-S15

Cite this article as: Gargiulo et al:: Use of statins in lower extremity artery disease: a review. BMC Surgery 2012 12(Suppl 1):S15.

\section{Submit your next manuscript to BioMed Central and take full advantage of:}

- Convenient online submission

- Thorough peer review

- No space constraints or color figure charges

- Immediate publication on acceptance

- Inclusion in PubMed, CAS, Scopus and Google Scholar

- Research which is freely available for redistribution 